August 1999 • NREL/SR-550-26842

\title{
Creating a Comprehensive Solar Water Heating Deployment Strategy
}

Focus Marketing Services

Westlake Village, California

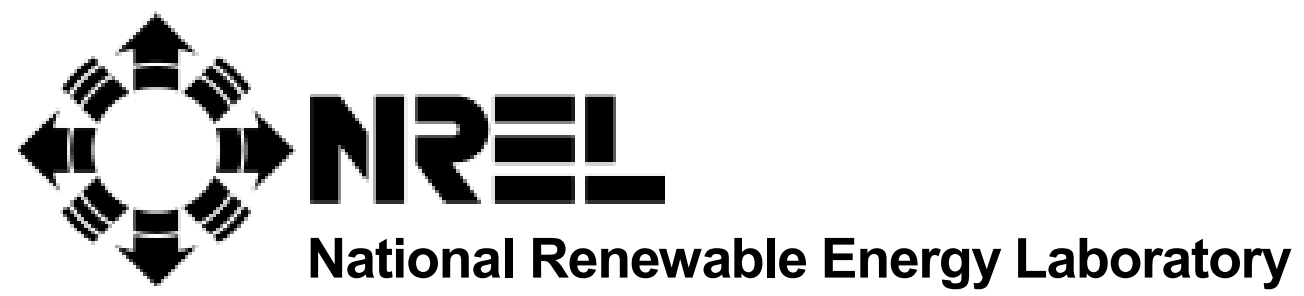

1617 Cole Boulevard

Golden, Colorado 80401-3393

NREL is a U.S. Department of Energy Laboratory

Operated by Midwest Research Institute $\bullet$ Battelle $\bullet$ Bechtel

Contract No. DE-AC36-98-G010337 


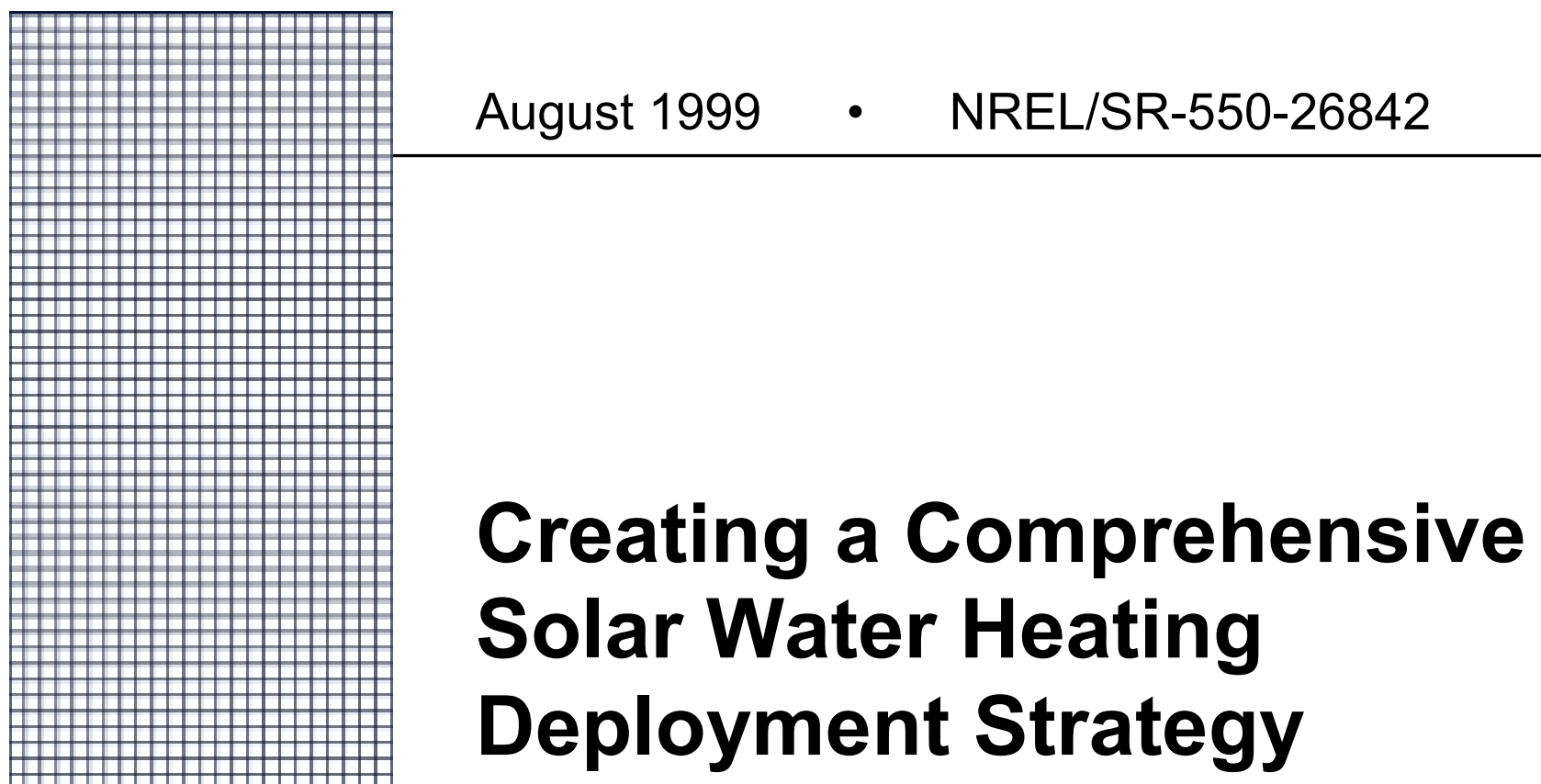

Focus Marketing Services

Westlake Village, California

NREL Technical Monitor: R. Hewett

Prepared under Subcontract No. AAD-7-17646-01

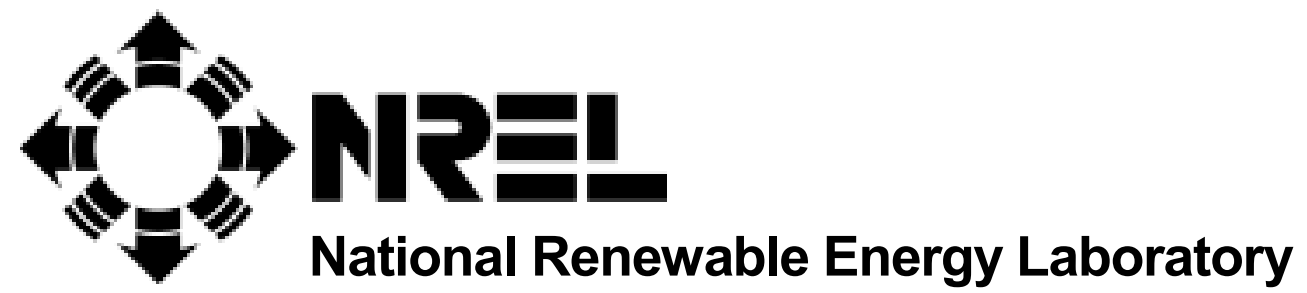

1617 Cole Boulevard

Golden, Colorado 80401-3393

NREL is a U.S. Department of Energy Laboratory

Operated by Midwest Research Institute $\bullet$ Battelle $\bullet$ Bechtel

Contract No. DE-AC36-98-G010337 
This publication was reproduced from the best available copy Submitted by the subcontractor and received no editorial review at NREL

\section{NOTICE}

This report was prepared as an account of work sponsored by an agency of the United States government. Neither the United States government nor any agency thereof, nor any of their employees, makes any warranty, express or implied, or assumes any legal liability or responsibility for the accuracy, completeness, or usefulness of any information, apparatus, product, or process disclosed, or represents that its use would not infringe privately owned rights. Reference herein to any specific commercial product, process, or service by trade name, trademark, manufacturer, or otherwise does not necessarily constitute or imply its endorsement, recommendation, or favoring by the United States government or any agency thereof. The views and opinions of authors expressed herein do not necessarily state or reflect those of the United States government or any agency thereof.

Available to DOE and DOE contractors from:

Office of Scientific and Technical Information (OSTI)

P.O. Box 62

Oak Ridge, TN 37831

Prices available by calling (423) 576-8401

Available to the public from:

National Technical Information Service (NTIS)

U.S. Department of Commerce

5285 Port Royal Road

Springfield, VA 22161

(703) $605-6000$ or (800) 553-6847

or

DOE Information Bridge

http://www.doe.gov/bridge/home.html

Printed on paper containing at least $50 \%$ wastepaper, including $20 \%$ postconsumer waste 


\section{EXECUTIVE SUMMARY}

\section{Objective}

National Renewable Energy Laboratory, under contract to the U.S. Department of Energy, and together with the Solar Energy Industries Association, has conducted research into a national product deployment strategy focused on introducing solar water heating into the new home market. The current report is a result of research carried out in 1998 and 1999, and outlines a marketing deployment plan designed for businesses interested in marketing solar water heaters in the new home industry.

The task was undertaken by reviewing research completed in 1998, which assessed the attitudes and interest on the part of consumers and homebuilders, to consider solar water heaters. Key points of this research were summarized in Task 2 of the subject report "Summary Report on Previous Market Research". A telephone survey was then conducted with building industry professionals in 1999 , to identify distribution channels used within this industry and the types of marketing methods employed to market products to builders or home buyers. This work was completed in Task 1 of the subject report, "Investigation of Distribution Channels and Marketing Methods in the New Home Industry".

From an understanding of this research, and from conversations with professionals in related service sectors and industries, the subject marketing strategy was developed to use as a template for solar manufacturers, builders, energy service providers, or other interested businesses. The marketing plan contains a brief summary of the background and current status of the industry for solar water heaters, an outline of potential opportunities in the building industry, and defines the marketing strategy including defining the product, distribution channel, pricing strategy and promotional mix. 


\section{Summary of Recommendations}

The greatest challenges faced by the solar industry include overcoming outdated images of solar water heaters, installers and manufacturers, as well as the challenge of re-educating homebuyers and builders on the key benefits. Fortunately, there is currently more attention focused on alternative energy sources and energy efficient products. Grants and programs created by independent organizations and alliances of government, professional associations and private industry, are now contributing to increased awareness and use of renewable energy resources.

To promote solar effectively to builders, the industry must address specific areas identified as key concerns by the builder including the level of homebuyer demand or acceptance, the cost of the product, and warranty coverage. Recognizing these factors, and with an understanding of consumer and builder attitudes based on past and current research, the following recommendations are the key elements of the proposed marketing strategy. Details of the full marketing plan are contained in the body of this report.

\section{Include solar water heaters as part of an energy efficient package offered} as a standard feature of the builder's new homes within a given community.

- This strategy serves to achieve economies of scale resulting in reduced pricing to the builder and the homebuyer. The homebuyer's monthly utility savings will also be enhanced by the inclusion of several energy efficient features.

- The builder can differentiate their product from the competition and strengthen their image as a quality builder.

Introduce the product in those markets where solar is most effective, notably in sunbelt states with higher dependence on electricity, where the cost savings to the consumer is amplified.

- Concentrating in those markets where the savings are greatest will provide the strongest opportunity to create momentum.

- Of the four markets researched for this report, Florida represents the greatest opportunity followed by Phoenix and Las Vegas, and finally California.

- Focus on passive solar technology, which is reliable in sunbelt areas and is the least costly alternative. 
Keep the current distribution channel intact for marketing to custom builders and remodelers; however, manufacturers should sell direct to production builders in order to achieve price levels that will allow more rapid product assimilation. Initial efforts should concentrate on the larger builders in each region.

- While the level of service and sales required for custom and some semicustom builders will be best served by the current distribution channel, builders in the production market will require a more cost effective solution to consider this product as a standard feature.

- Reducing the layers in distribution, while increasing volume as a result of the standard offering, should result in a significant price decrease to the builder, and thereby to the home buyer as well.

Design an expansive promotional mix including major emphasis on education and publicity to the consumer, as well as examples of case studies and currently selling communities made available to builders.

- Create alliances with other manufacturers of energy efficient products, government agencies, lenders and other organizations, to help promote the concept and further the goals of this industry.

- Generating consistent publicity, documenting case studies or currently selling communities, and providing sustained service and sales training for builder staff will assist in promoting sales. 


\title{
SOLAR MARKET DEPLOYMENT STRATEGY:
}

\author{
NEW HOMES MARKET
}

\begin{abstract}
Overview of the Solar Water Heating Industry
Solar water heating (SWH) technology was initially introduced on a wide scale in the residential market during the energy conscious 1970's. During this time period the industry experienced rapid growth when consumers received tax incentives to install solar water heating systems. Having experienced the gasoline shortages brought about by the Oil Crisis in 1973, and again in 1979, the public was very aware of the need to conserve consumable energy resources.

In its haste to capitalize on these tax incentives and the public's energy concerns, the industry failed to establish itself on sound consumer marketing principles. Most early installations were retrofits, and, lacking integration into the home design, the installed product was not aesthetically pleasing in many cases. With the incentive of an immediate tax break, the promise of annual savings on utility bills, and a good feeling for helping the environment, consumers purchased solar water heaters in significant numbers.
\end{abstract}

When the tax incentives expired during the mid-1980's, the sale of solar water heaters became much more difficult. With abundant, economical energy resources available to most consumers, the promise of annual savings on their water heating bill did not overcome the hurdle of the required initial investment.

Predictably, the size of the industry shrunk, reducing the number of manufacturers and installers. Although maintenance requirements on passive solar water heating systems, which are frequently used in new construction applications, are minimal, it was nevertheless disconcerting to homeowners to learn that in many cases the company that had installed their system was no longer in the business. Worse, the manufacturer was also out of business.

Today, the solar water heating industry has little market penetration with the exception of a few areas like Hawaii, where high energy costs provide a strong economic incentive for the consumer to install relatively efficient, active solar water heating systems as a cost and energy saving solution. Also, there are areas like Santa Barbara County, California, where a local building program gives the developer an incentive to install solar water heating and other energy efficient products on new homes. Incentives take the form of reduced processing time and reduced plan check fees, among others. 
Compared to the 70's, the average consumer is not as concerned about conserving energy. Although they respond favorably to the environmental connotations of solar water heating, they are nevertheless purchasing sport utility vehicles in record numbers with seemingly no regard for their high fuel consumption. The bell weather of energy availability, gasoline pricing, has remained low.

Many consumers today have access to natural gas. It remains a very low cost source of energy and is perceived as a clean source of energy. When compared to the cost of other utilities - water, electricity, telephone, internet access, heating, air-conditioning, sewage, etc. - the cost of heating water with natural gas each month is a small purchase for the average consumer. The new homebuyer is far more concerned about changes in mortgage interest rates and real estate taxes. However, heating water with electricity is still quite expensive, and in some areas natural gas is not available.

Current users of solar water heaters base their decision to purchase largely on their desire to save money. Like their predecessors, they also feel good about contributing to reduced dependence on fossil fuels and reduced pollution.

The materials of manufacture and efficiency of today's systems are virtually the same as in earlier years, however cosmetic changes have contributed to a smoother, more aesthetically pleasing product that resembles a skylight once installed. In research conducted for the National Renewable Energy Laboratory in 1998, focus group participants were asked their opinion of photographs of the newer designs installed on new homes. Most respondents expressed surprise at the more attractive appearance of today's systems. In subsequent telephone interviews, survey participants indicated they would be interested in learning more about solar water heaters after a brief description of these installations.

In 1980, the Solar Rating and Certification Corporation (SRCC) was formed to develop uniform rating standards and certification for solar water heating systems. This organization now provides an oversight function focusing on ensuring a level of efficiency and quality in system design that did not exist in earlier years. SRCC has developed a method for testing and rating solar water heating products to improve product performance and reliability. Systems are tested for durability, reliability, safety, and operation. Other factors that may affect system installation, maintenance and service are also evaluated. 
Additionally, entities such as the National Renewable Energy Laboratory and Sandia National Laboratory, under the auspices of the Department of Energy's Solar Buildings Program, are working with manufacturers of solar water heaters to improve solar building technologies and reduce costs. NREL and Sandia, in a long-term effort to explore the use of alternative materials in product fabrication and improve the manufacturing process, have teamed with solar industry members to develop new solar products which could be introduced in the next five to ten years.

Industry experts assert that sales of solar water heaters achieved one million installed units during the high point of the mid-1970's to mid-1980's, yet the solar water heater market today remains underdeveloped. The potential benefit of mass-market acceptance of solar water heating is enormous. To gain acceptance by the mass market, the solar water heating industry must re-build on a firm consumer marketing foundation.

Based upon our research and the research of others sponsored by DOE and NREL, the strategies outlined in this report provide a valid blueprint for the rebirth of this industry.

\section{Opportunities in the Building Industry}

For solar water heating to be accepted by consumers, the industry must strive to achieve "critical mass" in target markets. While there is the potential for significant consumer interest in solar in most markets, those areas not offering natural gas as an energy option offer the best potential for success.

The principal appeal of solar water heating to the consumer is lower energy costs. Although active systems produce greater savings, and may be required in non-sunbelt states, higher initial costs and higher maintenance requirements down the road are inherent in their design. Therefore, to gain penetration in the "best" solar markets, i.e. the sunbelt states, the industry should concentrate on passive systems.

To assure positive cash flow for the consumer, the industry needs to focus on delivering the product more efficiently to the consumer. With increased volume, the unit cost of production will come down. By offering the product as a standard feature, the builder and the manufacturer are assured of higher unit volumes. These higher volumes should yield economies of scale, resulting in lower investment costs for the consumer.

Once the builder is committed to the concept of offering solar water heating as a standard feature, there are other benefits. Working with the solar manufacturer, the architect can integrate the solar panels into the house design. By so doing, aesthetics are enhanced and panels can be placed for greatest solar efficiency. 
Compared to the total cost of home ownership, solar water heating is a relatively small item and has proven difficult to market as a stand-alone. Because of inherent inefficiencies associated with custom product options, solar water heating is less marketable as an option. Specifically, the roof design may have to be changed to integrate the solar water heating system, the decision on the option has to be made before the home is built out, and each installation becomes a "one off" situation leading to higher installation costs. Even if homes are pre-plumbed and roofs pre-designed, the cost of installation becomes greater as it is spread over fewer units.

The solution to the above dilemma is to package solar water heating as a standard feature within a total energy savings package. To appeal to the energy conscious consumer, the package should include superior products that save on overall utility bills and differentiate the builder's product line from the competition in a significant manner. Superior energy efficient features may include such products as dual paned low "e" windows, added insulation, high efficiency heating and air conditioning units and special mortgage financing. Builders in several states are already using this approach in the marketing and design of their new communities.

The builder can benefit from including an energy efficient package by differentiating their product from the competition, increasing consumer confidence in their product, and enhancing their company image as a quality builder.

The builder's customer benefits by lowered energy costs, less reliance on public utilities, an improved quality of living and incentives that may be available through mortgages or tax savings. Arizona, for example, presently offers a personal income tax credit covering $25 \%$ of the solar water heater cost to purchasers, to a maximum of $\$ 1,000$.

Several new home communities have installed solar photovoltaic panels (PV), which help generate electricity as part of a total energy package for the home. $\mathrm{PV}$ is a new technology for the home and, as such, requires buydowns or subsidies to be economically viable due to its present day cost. Further, PV, like solar water heating, requires extensive promotion and consumer education to attract homebuyers. Once educated on the benefits of renewable energy and energy conservation, the consumer is a natural candidate for SWH based on its relatively favorable economics. SWH is a proven energy saving technology which should be a part of every PV project.

With deregulation of the energy industry, there are opportunities for program support from the major utility companies. Several utility companies have already embraced or are currently exploring solar water heating as an alternative energy source. Examples include the Sacramento Municipal Utility District (SMUD) and Nevada Power. The program offered by SMUD provides a rebate to builders 
applied against line extension fees. The amount of the rebate is based on the percentage by which a builder exceeds California's Title 24 energy requirements. Nevada Power is now supporting the installation of SWH systems in the new home market in conjunction with Pulte Homes, who offers a mortgage interest rate reduction for solar water heating purchasers in the first of several planned Las Vegas developments. Nevada Power's support includes information about the first community tucked in the customer's billing statement and featured in newsletters.

The Los Angeles Department of Water \& Power (DWP) is also currently developing a program to offer solar water heating systems to its customers. They would like to be able to deliver a SWH system to their customers for under $\$ 1,000$. There is very little new home construction within DWP's market area, so they will be concentrating on the existing home market.

The Salt River Project in Phoenix is an example of another energy provider reviewing solar water heating as an alternative energy option. Obviously, the involvement of well-established and recognizable companies makes solar water heating more attractive to the consumer.

For the solar water heating industry, energy providers or other entities interested in a solar water heating program, the goals of its marketing program would be the following:

- Increase market penetration in target markets

- Educate the consumer to focus on the monthly cash flow benefits of SWH systems.

- Dramatically reduce the initial investment costs for the consumer, while maintaining profitability for the manufacturer through the following -

- Economies of scale

- Distribution efficiencies

- Utility company program subsidies

- City or county building incentive programs

- Tax credits or subsidies

- Gain broad acceptance of solar water heating as a standard, main stream product.

It is not clear that this program for the new home industry would directly benefit current solar water heating contractors/installers. In many cases the builder may choose to select an alternate installation method to gain efficiencies. For example, the builders may choose to buy the solar water heating equipment direct from the manufacturer and have it installed by their own personnel or by another sub-contractor (e.g. the plumbing contractor). However, in some states licensing laws require that installations be done by licensed solar contractors. 
Nevertheless, if the program is successful, the traditional solar water heating installer should reap rewards by being assimilated into the new construction market for solar, or into the remodeling/retrofit market. There are many successful contractors serving the owners of older homes by bringing their houses up to current standards. Dual pane windows, new paint coatings, increased insulation, and code compliance upgrades are all products now being offered successfully to the owner of older homes. The success of solar water heating in the new home market may also breed success for the established installer in the existing home market.

\section{Marketing Objectives and Strategies}

Today, the solar water heating industry offers attractive products that can provide savings to consumers on their monthly utility bill. Passive, or Integral Collector Storage (ICS) products are best suited for warmer climates, where simpler system designs can be used since the danger of prolonged freezing weather is minimal and sunshine is abundant. A solar water heating system, like all products using renewable energy sources, reduces consumption of depletable energy sources and thus benefits society.

Although sometimes giving mixed messages, the consumer is interested in improving the environment when it can be done for little or no out-of-pocket cost. Consumers are very interested in energy saving appliances that generate dollar savings for the family.

For many consumers, solar water heating can offer a real economic advantage. However, because there are many factors that enter into the economics of solar water heating, it has proven difficult to communicate clear benefits to the consumer.

Therefore, a successful SWH program must concentrate its efforts on those market segments that offer the highest potential for consumer savings or in areas where other market factors make acceptance likely. Through penetration of these segments, the consumer will begin to accept solar water heating as an integral part of their household appliance package.

Fortunately, the solar industry can influence the economics of the SWH system, making it more attractive to the consumer. Indeed, successful penetration of selected market segments will increase manufacturing volumes and lead to economies of scale that can be passed on to the consumer. Reduced initial investment and improved distribution and installation of solar water heating systems will make them more attractive and accelerate market acceptance of the product. 


\section{Economic Factors}

The economic benefit of solar water heating is dependent upon many factors. The industry should target those markets that have the highest potential for economic benefit. For those factors it can control, the industry should strive to improve the potential benefits to the consumer. By so doing, it will accelerate market acceptance of solar water heating and prosper from the market growth.

The following table summarizes the principal economic factors and the potential for improvement by the industry:

\begin{tabular}{|l|l|l|}
\hline Economic Factor & Comment & Potential for Improvement \\
\hline $\begin{array}{l}\text { Unit Cost of } \\
\text { Energy }\end{array}$ & $\begin{array}{l}\text { Electrical energy is generally } \\
\text { the most expensive energy } \\
\text { source. Therefore, when } \\
\text { electrical energy is the } \\
\text { primary source for water } \\
\text { heating, solar water heating } \\
\text { offers the highest potential } \\
\text { savings. }\end{array}$ & $\begin{array}{l}\text { All new home projects must } \\
\text { have electrical energy. By } \\
\text { including solar water heating } \\
\text { and lowering the consumer's } \\
\text { electric bill, the builder has less } \\
\text { need to include natural gas. }\end{array}$ \\
\hline $\begin{array}{l}\text { Consumption of } \\
\text { hot water }\end{array}$ & $\begin{array}{l}\text { The more hot water the } \\
\text { consumer uses, the greater } \\
\text { the benefit of solar water } \\
\text { heating. }\end{array}$ & $\begin{array}{l}\text { Increased use of hot water runs } \\
\text { completely counter to the } \\
\text { environmental benefit of solar } \\
\text { water heating. }\end{array}$ \\
\hline $\begin{array}{l}\text { Efficiency of solar } \\
\text { water heating }\end{array}$ & $\begin{array}{l}\text { The more efficient the } \\
\text { system, the greater benefit to } \\
\text { the consumer. }\end{array}$ & $\begin{array}{l}\text { By working with builders and } \\
\text { architects, the solar industry } \\
\text { can assure systems are } \\
\text { installed for maximum } \\
\text { operating efficiency. }\end{array}$ \\
\hline $\begin{array}{l}\text { Initial cost of the } \\
\text { system. }\end{array}$ & $\begin{array}{l}\text { The initial cost to the } \\
\text { consumer is affected by the } \\
\text { manufacturer's cost, markups } \\
\text { in the distribution system, } \\
\text { labor costs and profit margins } \\
\text { of the installer, and in certain } \\
\text { markets, any energy credits } \\
\text { available from the } \\
\text { government or local utilities. }\end{array}$ & $\begin{array}{l}\text { Manufacturers should examine } \\
\text { how to improve the efficiencies } \\
\text { of manufacturing, distribution, } \\
\text { installation and selling to } \\
\text { reduce the investment } \\
\text { required. The lower the } \\
\text { investment, the more likely the } \\
\text { consumer will see a benefit. }\end{array}$ \\
$\begin{array}{l}\text { maintenance history of } \\
\text { passive ICS systems is } \\
\text { excellent and easily } \\
\text { understood by the consumer. }\end{array}$ & $\begin{array}{l}\text { Even though active systems } \\
\text { are more efficient, where } \\
\text { possible the industry should } \\
\text { emphasize passive systems } \\
\text { because of their proven } \\
\text { reliability and low maintenance } \\
\text { costs. }\end{array}$ \\
\hline $\begin{array}{l}\text { Maintenance } \\
\text { costs. }\end{array}$ & $\begin{array}{l}\text { and } \\
\text { and }\end{array}$ \\
\hline
\end{tabular}




\section{Market Potential and Objectives}

The markets selected for a national deployment strategy for solar water heating products include California, Florida and the metro markets of Phoenix, Arizona and Las Vegas, Nevada. Statistics reported in the May issue of Housing Economics (published by NAHB) indicate that in 1998 and year-to-date in 1999, Phoenix is the second most active metro market in the United States for singlefamily dwellings based on the number of permits pulled. Of the four markets included in this study, in 1998 Florida was the most active state and California was the second most active.

According to NAHB, projections for housing starts in1999 and the year 2000 indicate continued strength in all selected markets:

\begin{tabular}{|l|l|l|l|l|}
\hline Market & $\begin{array}{l}\text { Permits 1Q } \\
\mathbf{1 9 9 9}\end{array}$ & Permits 1998 & $\begin{array}{l}\text { Projections } \\
\mathbf{1 9 9 9}\end{array}$ & $\begin{array}{l}\text { Projections } \\
\mathbf{2 0 0 0}\end{array}$ \\
\hline California & 21,360 & 93,410 & 103,400 & 101,200 \\
\hline Florida & 25,430 & 97,890 & 110,000 & 104,500 \\
\hline Las Vegas & 5,660 & 21,630 & 31,146 & 30,140 \\
\hline Phoenix & 10,140 & 36,560 & 48,076 & 47,374 \\
\hline Totals & $\mathbf{6 2 , 7 8 0}$ & $\mathbf{2 4 9 , 4 9 0}$ & $\mathbf{2 9 2 , 6 2 2}$ & $\mathbf{2 8 3 , 2 2 3}$ \\
\hline
\end{tabular}

First year goals for solar water heating are based on projections for the year 2000 , and the promotion of solar water heating as a standard feature included in an integrated energy package. Activity is anticipated to increase as construction of new communities increases and the product gains market acceptance:

\section{Milestones}

First year

Second year

Years 3-5

\author{
Number Single Family \\ 1,200 units \\ 2,500 units \\ 12,000 units $(4,000$ /year $)$
}

Market Share

$0.5 \%$ of 1998 total

$1 \%$ based on 1998 total

$4.8 \%$ based on 1998 total

The initial year's goal is based on an average of 300 units per market, and assumes three to six builders per market sign on to construct and sell 50 to 100 homes in the first year. Although averages have been used to reach the objectives, there will probably be heavier activity in the priority market in the first year, and there may be little or no activity in the least favored market until the second year. As Florida is the strongest candidate for solar water heaters, in actuality the larger number of sales will probably occur in that market. Numbers are based on 1998 figures for single family permits pulled. These objectives do not take into account future effects of interest rate changes or other economic factors that can effect the level of activity in the building industry. 
It is important to note that time delays will be inherent in sales to the building industry. From the time a builder accepts the concept to implementation on a new home project, six months or more could elapse. It is not uncommon for a new development to take one year or longer to open for sales. This time is used to design the new home product for the market, obtain city and/or county approvals and permits, and begin actual construction. The time frame varies with different regions. The initial sales goals outlined here may appear to be modest, but are in fact somewhat ambitious.

As reported in the May 1999 issue of Builder magazine, the top 100 builders in the country had a $21.5 \%$ share of the single family market in 1998 . Combining single family and multi family dwellings, the top 100 builders had $20.4 \%$ market share. This number has increased steadily since 1994 when the top 100 builders had $13.4 \%$ market share. Larger builders are the primary target to ramp-up sales for solar water heating.

Solar manufacturers should be prepared to address the concerns of large builders including warranty issues and the effects of installation on adjacent materials (such as roofing), the reliability of what they may consider an "unproven" product, and the extent of consumer acceptance or demand. Larger builders have greater exposure in the marketplace and want to protect their hardearned reputations. They also seek to minimize risks associated with offering new product types.

Regional builders also play a potentially important role in introducing SWH to the new home market. Regional builders may have greater market share in a given area, making them a more effective candidate to utilize solar water heating effectively. They may also be more willing to take perceived risks associated with offering a new product type. In turn, they can reap the potential benefits of improving their company image and sales by offering a more efficient, comfortable home to their customers.

While it is difficult to pinpoint the market segments that may be most responsive to this product, move-up buyers are logical prospects. Move-up buyers typically form a significant segment of the production builder's customer base. Having paid utility bills since owning their first home, and with growing families leading to increasing expenses, they may find energy savings very attractive. Price ranges for these homes will vary by region.

Additional market segments that may prove receptive to solar water heating include resort properties, custom homes, properties designed as second homes, and communities built in remote locations, where the cost of bringing in utility lines is higher. 
Florida provides the greatest potential for absorption as electric water heaters are used more commonly in this market than in California, for example, and the market is active in all price ranges and categories. The strategy would place the greatest priority on marketing the new concept in Florida and branching from that area to Las Vegas, Phoenix and California. California is the state with the greatest penetration by the gas industry, and therefore offers a potentially slower growth rate.

\section{Product}

Passive solar water heaters are recommended for reasons stated earlier, including their lower installed cost, durability and low maintenance. Passive systems generally feature the following elements:

- Roof mounted insulated box with a glass coverplate;

- Interior tanks that collect solar energy and store the water being heated;

- Piping leading into and out of the system feeds heated water to the home.

These passive systems are available in varying sizes, with capacity ranging from 30 to 50 gallons or more. The roof must be able to support the weight of the desired system. In new construction applications, the same size system is usually installed on every home, rather than trying to match varying system sizes to the number of occupants in each home.

Solar systems are always paired with a conventional water heater to accommodate a family's need in the event of prolonged cloudy weather or higher volumes of hot water usage. A solar water heater reduces a family's dependence on conventionally heated water, thereby reducing energy consumption and contributing to a lower utility bill. One added benefit to the builder is the potential to purchase a smaller conventional heater as a back-up system, as the SWH would provide additional storage capacity.

The product that is offered today by the solar water heating industry is aesthetically acceptable to most consumers. The manufacturers continue to strive to improve the aesthetics - the solar panels or integral collector storage (ICS) system will be acceptable to all consumers when they are unobtrusive and resemble a skylight. Here are some examples of contemporary installations. 
Photo Number 1

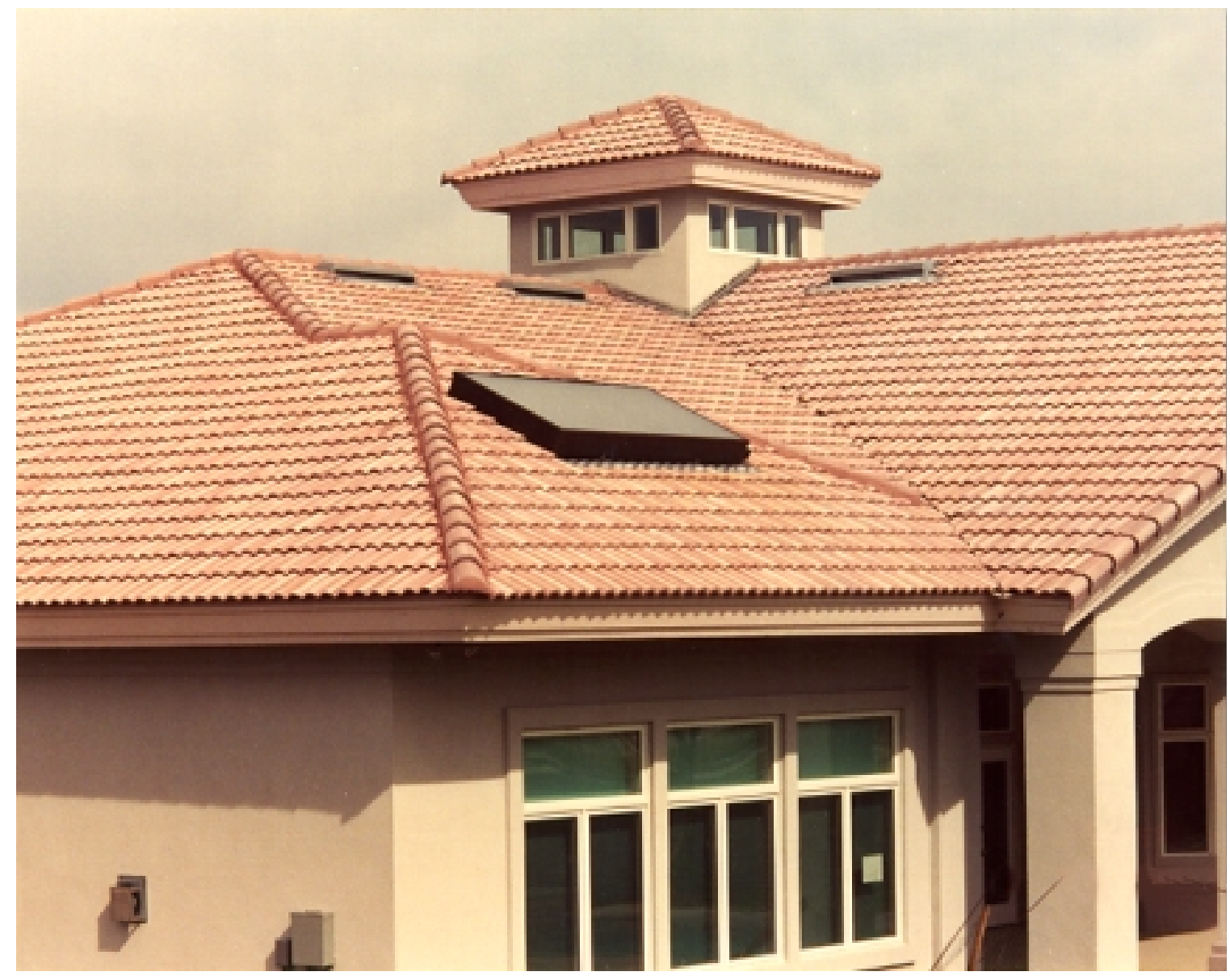


Photo Number 2

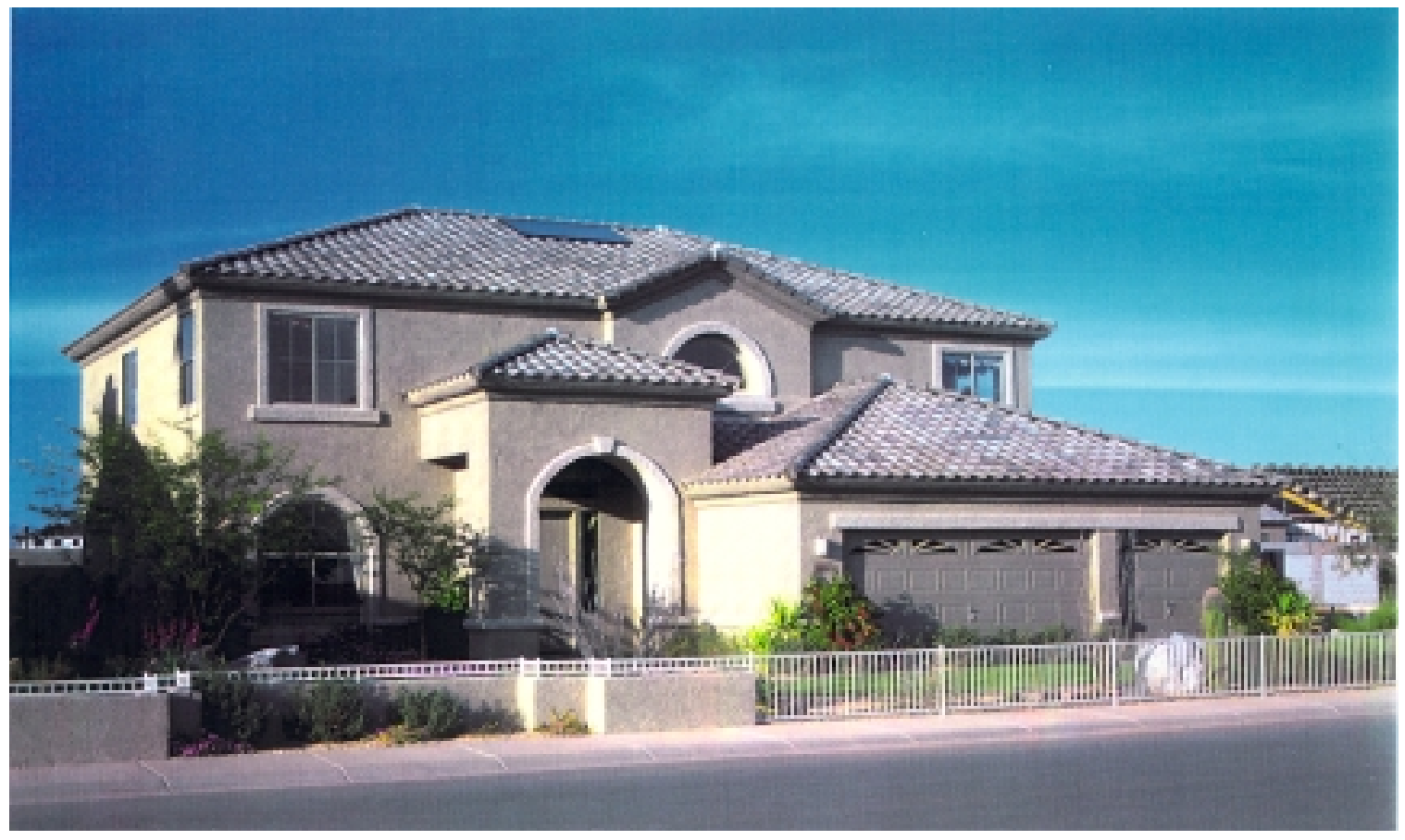

Photo Number 3

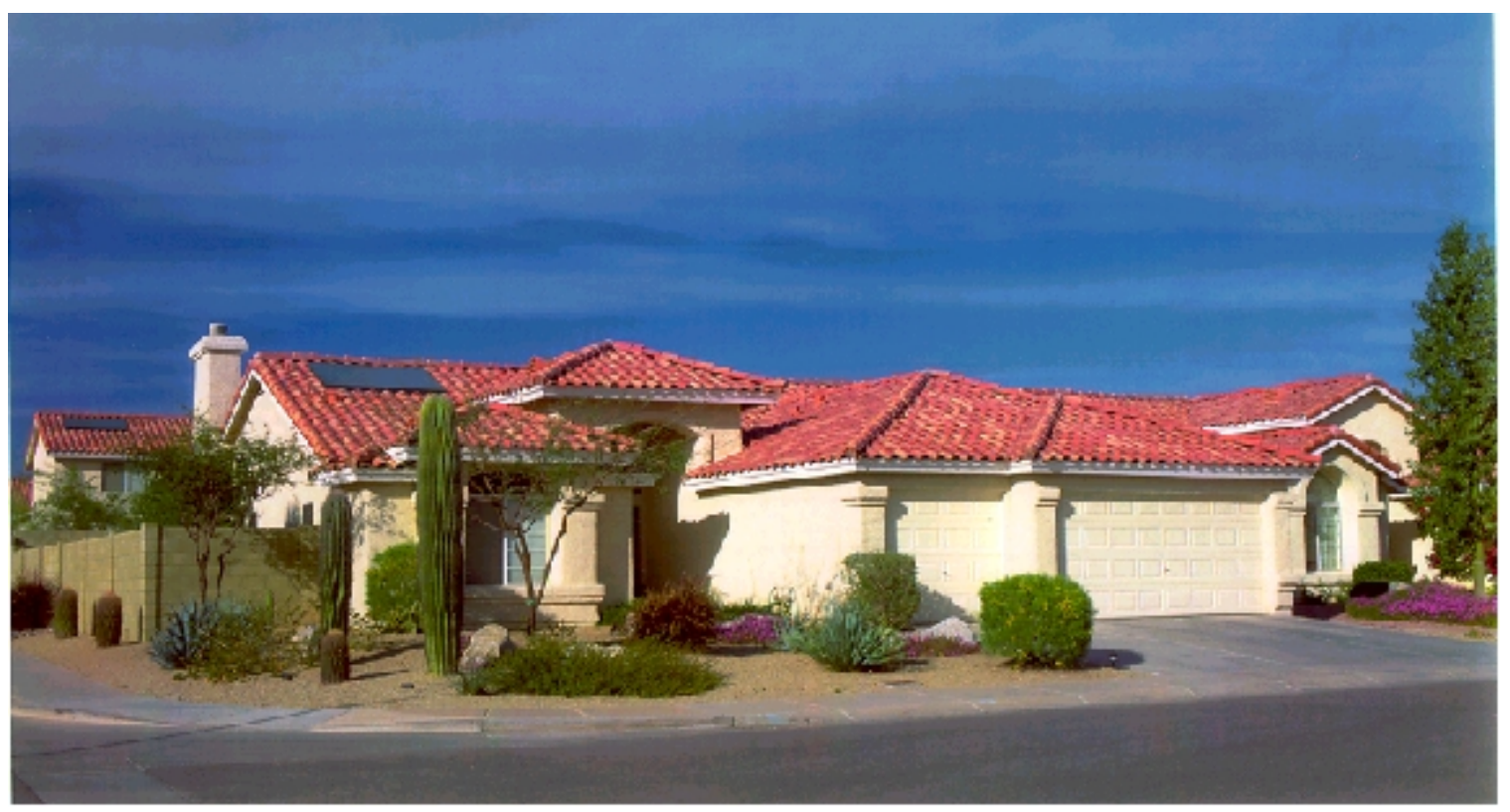


The example shown in Photo Number 2 is the best from an aesthetic viewpoint. The color of the solar panel blends with the gray roof. In the other two examples, the panels are more visible. All three examples of contemporary installations are far superior to the installations of the 70s and 80s, which in many cases looked like afterthoughts and did not conform to the basic style of the house.

The improved cosmetic design can be flush mounted to the roof, and the manufacturer should provide information and/or training to ensure a proper installation, protecting the home from leaks or other damage.

Product warranty is another critical component of the product offering and a major concern for builders. As they typically provide homeowners a ten-year warranty on structural features, they are sensitive to products that may affect the warranty. Solar manufacturers must carefully consider the term of their product warranty, and also consider the potential impact of this device on the roof of the home. Manufacturers must be prepared to offer proper training and technical information to those trades which may be involved in installation, including roofers and plumbers.

\section{Distribution}

Today, most solar water heating systems are reaching the market through a twostep distribution system. They are shipped from the manufacturer to a wholesaler, either a plumbing wholesaler or a specialty solar wholesaler. The wholesaler, in turn, sells to a solar installer who sells to the builder or direct to the homeowner.

This distribution system works very well for the remodel or retrofit market. As evidence of its appropriateness, industry experts estimate that retrofit systems sold currently outnumber systems for new construction by a factor of approximately ten to one.

Research recently conducted for NREL indicates that, regardless of how building product manufacturers distribute their products, they rely on their in-house sales force to sell to the builder. Although direct selling is expensive for a manufacturer, it must be a key component in a penetration strategy of selected new home markets. The manufacturer simply cannot rely upon a third party to carry the message to the builder.

The solar manufacturer must establish a relationship and demonstrate their commitment to support the builder's sales. In effect, the manufacturer creates an alliance with the builder, treating them as a national account and providing superior service. This direct sales program is most effective for the production market segment and may also prove appropriate for larger luxury production (semi-custom) builders. 
While this self-reliance in sales on the part of the manufacturer reduces the value of the middleman in mainstream production building, the traditional distribution channel more effectively supports the custom market. To support product sales to this homebuilding category, there are a greater number of individual contacts that must be made and more detailed support required for homes that are individually designed and built. A local solar installer can provide the quality of service that is required for a more detailed custom product. The price point of this market segment can absorb the larger margin inherent in this distribution channel as a trade-off for the more labor intensive sale and support system.

The custom market represents a strong opportunity for these installers, as the more price discretionary homebuyer is more involved in deciding what products will be used in their new home. This implies that the installer must market not only to the custom builder, but to the consumer and the architect as well, as the product should be considered while the home is in the design stage.

Within the target markets, a relatively small number of builders dominate the new home construction market. The manufacturer should concentrate the selling effort on the largest builders within each market. The sales goal is to sign up the builders for a total energy package featuring solar water heating. Although there may be some step-up options, basic solar water heating must be a standard feature for the new home project.

A properly trained, senior salesperson can concentrate activities on these four markets with an organized plan in place. The plan would lay out the priority for market areas, key submarket metro areas for each, largest builders within target submarkets, and key contacts for each builder in each submarket. Utilizing a well-organized approach, and appropriate promotional materials as well as referencing new home developments currently employing similar methods of product differentiation in other national markets, the salesperson can tell the story of solar water heating in the new home industry.

Once key targets are established in the top priority region, the salesperson can take those success stories to the next target market and continue the contacts. Each market should be revisited on a regular basis, to improve upon existing relationships, as well as to continue to tell the story and generate new builder participants.

Through success in selling this concept, the manufacturer can effect significant economies in delivering product to the new home. First, he can build the solar water heaters to order, delivering just in time and avoiding the cost of inventory. Second, he can eliminate the middleman's markup, reducing the cost to the builder. Third, he can encourage the builder to use the least cost installation method. 
Specific implementation will vary by market. In some cases, the builder will want to have the product delivered to his installer or he may have it delivered to the jobsite. If the installer is his plumbing subcontractor, this represents incremental business to the plumber. The builder should be able to negotiate an installation cost with the installer that includes a fair markup on labor, but not the customary markup on equipment.

The goal is to deliver solar water heating at the least cost without damaging manufacturers' margins, yet providing an incentive for the builder. The key elements for achieving this goal include:

1) By offering solar water heating as a standard product, the volume of units shipped is higher and more predictable. This leads to economies of scale and efficiencies of scheduling.

2) Selling and shipping direct to the builder (or his designee) eliminates the middleman's margin.

3) By efficiently installing solar water heating as a standard feature, the builder can offer the consumer the following:

a) The delivered cost of the system should be approximately half the cost of a system purchased as a retrofit for an existing home.

b) The consumer will enjoy a lifetime of reduced utility bills with little expectation of future high maintenance costs. In fact, he will probably spend far more replacing a conventional hot water heater over time than he will in maintaining a passive (ICS) solar water heating system.

c) The consumer has the satisfaction of helping the environment.

d) Because the system is designed into the house as a standard feature, the consumer has an aesthetically acceptable system and one that operates most effectively.

e) The consumer will have a significantly greater supply of hot water.

The manufacturer should be prepared to provide on-site installation training for the subcontractor(s) who will be installing the solar product. In many cases the subcontractor will have had little or no experience with solar products, and handholding on the first installation or two will have substantial benefits. Even when the subcontractor has prior solar experience, the roof integration aspect of installation on new construction should be carefully worked out. 


\section{Pricing}

Research conducted for NREL and the Solar Energy Industries Association in 1998 revealed that prospects for solar water heaters were less likely to consider purchasing the product if the price was higher than $\$ 1,500$. Interest dropped dramatically if the price rose to $\$ 2,000$ or higher. However, later consumer market research has shown that if a positive or even neutral monthly cash flow can be demonstrated as a result of installing a solar system, the issue of first cost is diminished. Tellingly, this monthly cash flow approach has been embraced by the U.S. Environmental Protection Agency's Energy Star Home Program, where discussion of first cost is minimized in favor of reduced ongoing operating costs.

Currently, estimates on the installation of passive solar water systems range from $\$ 1,800$ to $\$ 2,500$ in new construction applications. The most commonly quoted figure is $\$ 2,200$. Improvements in distribution methods and installation savings resulting from "standard" vs. "option" installations will lead to lower prices. Ongoing efforts are being made to reduce the cost of the technology, however these efforts are not expected to yield significant cost reductions in the next five years.

Manufacturers may initially need to adopt a strategy that includes leaner margins per unit in order to gain exposure in the building industry. The economy of scale achieved by inclusion of solar water heaters as part of a standard energy package should allow manufacturers and installers to adopt a more flexible pricing strategy. Margin will be regained with increase in volume rather than through sales of individual systems.

The maximum recommended installed price for sale to the builder is $\$ 1,500$. It is highly advisable to reduce that number, either through refinements in production or other means, with the goal of entering the market near or under $\$ 1,000$ per unit. Offered as a standard feature, the builder may mark up SWH consistent with the overall profit margin for the project. Typically, this is lower than the margin the builder requires for options, which results in greater savings to the homebuyer.

Pricing must remain sensitive to the fact that other costs may be associated with installing the $\mathrm{SWH}$, including such items as the roofer's cost to integrate the unit. The ability to accomplish this pricing goal will rest with the more efficient distribution channel and with each manufacturer and the installer. The more competitive the installed cost, the greater will be the ability of builders to afford this feature.

Programs such as volume incentive rebates may also prove effective as sales advance, used chiefly as a tool to build loyalty and increase the sales rate. However, the initial effort must be provided up front in the form of lower system cost to gain entry into the market. 


\section{Promotional Mix}

One of the most important aspects of the market deployment strategy includes communicating the benefits and new product refinements to both builders and homebuyers. Marketing communication materials must deliver the appropriate message to builders by addressing their top concerns, including brand name recognition, cost efficiency and consumer demand. The promotional mix should include:

- Continuous PR campaigns to promote awareness among builders and homebuyers;

- Creating alliances with energy service providers and other manufacturers of energy efficient products;

- Providing valid case studies or demonstration communities that support energy claims and showcase consumer acceptance;

- Full utilization of available government sponsored programs;

- Participation in builder associations and trade shows in target markets;

- Advertising to builders and architects in their trade publications;

- Technical and design support to builders, installers, utilities and architects;

- Promotional materials made available to builders for their sales offices;

- Model home programs to defray the cost of product display;

- Sales training for builder sales staff and design center staff.

Existing solar water heater manufacturers have a history of product support and development that should be promoted in their literature. Their longevity and commitment to solar products should be touted to generate consumer and builder confidence. Experience and involvement in the new home industry should also be indicated.

Delivering the message to homebuyers means generating publicity for new home communities that have signed on to offer solar water heaters. Creating press releases for distribution in local publications, including newspapers and magazines, announcing new solar communities will be a central part of this endeavor. The solar industry trade associations may also be able to utilize funds to advertise and promote the new appearance of the installed product as well as the benefits of ownership. This will serve to raise consumer awareness.

Creating alliances with public utility companies and providing information for their energy saving information pamphlets and promotions will also gain the consumer's attention and confidence. The energy service providers will benefit by gaining recognition among their customers as leaders in energy products. 
Solar manufacturers should also consider enlisting the support of additional trades and manufacturers by creating alliances that serve to promote energy efficient packages as a method of product differentiation and niche marketing for builders. Key players could include insulation companies, window manufacturers, and other appliance manufacturers. Together as an alliance, they can help promote a package of superior energy products and create referrals for each other's business.

The ability to illustrate product acceptance and efficiency with case study examples or referrals to existing new home communities will strengthen the presentation to the builder. With additional valid evidence to support industry claims, builders will be encouraged to seriously consider energy efficient packages and solar water heaters.

Energy efficient packages should also include supporting products such as Energy Efficient Mortgages, and participation in programs like the Energy Star Homes program, Solar Buildings program, HERS or similar rating and certifying programs adopted by the DOE and EPA or professional building associations.

Energy efficient mortgages offer particular advantages to home sales as they may include below market interest rates, contributions toward closing costs, or easier qualifying criteria, allowing the homebuyer to afford a larger mortgage. Energy efficient mortgages are currently offered by several lenders and more may become involved as the concept gains popularity. Presently, energy efficient first mortgages are available as conventional, FHA and VA loan programs. These loans are available based on the ability of the qualifying home to surpass the national Model Energy Code by $30 \%$.

Participation in building trade associations will show dedication to the industry and increase exposure. Regular advertising in trade publications will increase awareness and can generate builder leads for the manufacturer's sales staff. Participation in major building industry trade shows and at smaller, regionally important trade shows will also contribute to building awareness within the industry.

Specific promotions to step up the incentive should include no-charge brochures for the builder's sales agent to provide at the model complex or design center. A model home program should be established to provide the product at a substantial discount for the model homes. This discount may be upwards of $25 \%$. Deeper discounts or offering the demonstration product for the models free of charge will likely create more interest for home builders, as it eases their budget constraints and provides them with the tools they need to promote their energy efficient package. Additionally, creating point-of-purchase displays to draw the home shoppers' attention to the presence and effectiveness of solar water heating will also serve as an additional sales tool and support the efforts of the on-site agent. 
The manufacturer or other solar system provider should also create training materials that will allow the on-site sales agent to accurately portray the benefits of solar water heaters, along with the other features of the homes they will be promoting. This effort is key to enlisting their support and assisting them in properly representing the builder's homes. Training materials should be simple, and the message should be direct and clear. 


\section{Appendix}

The following is a list of sources consulted in the preparation of this marketing plan. This list does not include reference to any private workshops or interviews with various building industry professionals, or members of other organizations, that may have been conducted in the design and research for this report.

Lofland, L.; FOCUS Marketing Services, January 28, 1998

"Deliverable 8: Draft Final Report Documenting Results from Analysis of Task 2 Qualitative Research, Findings, Conclusions and Recommendations to NREL \& The Solar Industry."

Lofland, L.; FOCUS Marketing Services, March 13, 1998

"Deliverable 8: Draft Final Report Documenting Results from Analysis of Task 1 Quantitative Research, Findings, Conclusions and Recommendations to NREL \& The Solar Industry."

Maynard, Roberta; and Depietropaolo, Rebecca; Builder magazine, May 1999, publisher Hanley-Wood, Inc., "Builder 100: What's New This Year."

National Association of Home Builders, May 1999, Housing Economics, "Building Permits", pages 24-27.

NAHB Research Center, Inc., January 1998

"Opportunities for Solar Water Heating: Final Report."

Rogers, Henry H. II; Shirley, Larry E.; North Carolina Solar Center, North Carolina State University, 1996; "The National Database of State Incentives for Renewable Energy: Abstract." And Interstate Renewable Energy Council and the North Carolina Solar Center "National Database of State Incentives for Renewable Energy."

Solar Rating and Certification Corporation, internet website, "History of SRCC", "Solar Collector Certification Program", "Solar System Certification Program".

Symmetrics Marketing Corporation, June 1998

"SRP/NREL New Home Buyer Solar Water Heater Trade-off Study: Summary Report for Public Release."

U.S. Department of Energy, Renewable Energy Annual 1996, issue April 1997, Chapter 6: "Solar Industry Profile". 
U.S. Department of Energy, Energy Efficiency and Renewable Energy Network, Fact Sheet: "Solar Water Heating".

U.S. Department of Energy, Solar Buildings Fact Sheet: "Program Description".

U.S. Department of Energy, September 1998; "The Borrower's Guide to Financing Solar Energy Systems: A Federal Overview".

U.S. Environmental Protection Agency, Energy Star Homes Program, Fact Sheet: "Energy Star Homes Benefit Mortgage Providers"

Wong, P.E.; Leber, P.E.; and Sugar, John, Manager; Energy Efficiency Division, California Energy Commission, May 1996

"Analysis of Various Water Heating Systems." 
Public reporting burden for this collection of information is estimated to average 1 hour per response, including the time for reviewing instructions, searching existing data sources, gathering and maintaining the data needed, and completing and reviewing the collection of information. Send comments regarding this burden estimate or any other aspect of this Davis Davis Highway, Suite 1204, Arlington, VA 22202-4302, and to the Office of Management and Budget, Paperwork Reduction Project (0704-0188), Washington, DC 20503.

\begin{tabular}{|l|l|l|}
\hline 1. AGENCY USE ONLY (Leave blank) & $\begin{array}{l}\text { 2. REPORT DATE } \\
\text { July } 1999\end{array}$ & $\begin{array}{l}\text { 3. REPORT TYPE AND DATES COVERED } \\
\text { Subcontract Report }\end{array}$ \\
\hline
\end{tabular}

4. TITLE AND SUBTITLE Creating a Comprehensive Solar Water Heating Deployment Strategy

5. FUNDING NUMBERS

SH71 5004

6. AUTHOR(S)

Focus Marketing Services

7. PERFORMING ORGANIZATION NAME(S) AND ADDRESS(ES)

Focus Marketing Services

2899 Agoura Road, Ste. 223

Westlake Village, CA 91361

8. PERFORMING ORGANIZATION REPORT NUMBER

SR-550-26842

National Renewable Energy Laboratory

1617 Cole Boulevard

Golden, Colorado 80401-3393

9. SPONSORING/MONITORING AGENCY NAME(S) AND ADDRESS(ES)

10. SPONSORING/MONITORING AGENCY REPORT NUMBER

U.S. Department of Energy

1000 Independence Ave., SW

SR-550-26842

Washington, DC 20585

11. SUPPLEMENTARY NOTES

12a. DISTRIBUTION/AVAILABILITY STATEMENT

12b. DISTRIBUTION CODE

National Technical Information Service

U.S. Department of Commerce

5285 Port Royal Road

Springfield, VA 22161

13. ABSTRACT (Maximum 200 words)

This report details the results of a research conducted in 1998 and 1999 and outlines a marketing deployment plan designed for businesses interested in marketing solar water heaters in the new home industry.

14. SUBJECT TERMS water heating, solar water heating, marketing, business plan, solar energy

15. NUMBER OF PAGES

24

16. PRICE CODE

17. SECURITY CLASSIFICATION OF REPORT unclassified

18. SECURITY CLASSIFICATION OF THIS PAGE unclassified
19. SECURITY CLASSIFICATION OF ABSTRACT unclassified
20. LIMITATION OF ABSTRACT

UL

NSN 7540-01-280-5500

Standard Form 298 (Rev. 2-89) Prescribed by ANSI Std. Z39-18 